\title{
ZASTOSOWANIE SYSTEMÓW INFORMACJI GEOGRAFICZNEJ (GIS) W DYDAKTYCE GEOGRAFICZNEJ PRZYKLAD ĆWICZEŃ TERENOWYCH „GEOGRAFIA TURYZMU I HOTELARSTWA”
}

\begin{abstract}
Zarys treści: Celem artykułu jest przedstawienie możliwości zastosowania Systemów Informacji Geograficznej (GIS) dla celów dydaktycznych na kierunku Turystyka i Rekreacja na przykładzie ćwiczeń terenowych „Geografia turyzmu i hotelarstwa”. Zasięg przestrzenny badań terenowych, prowadzonych w ramach ćwiczeń, obejmował obszar sołectwa Spała. Podczas ćwiczeń zastosowano dwie przestrzenne metody określenia funkcji turystycznej: zdjęcie użytkowania ziemi oraz bonitację punktową. Ćwiczenia zrealizowano z użyciem technologii i narzędzi GIS, w tym oprogramowania ArcGIS 10.4 (desktop) oraz umożliwiającego pracę w chmurze portalu ArcGIS Online. Przeprowadzone ćwiczenia pozwoliły na scharakteryzowanie funkcji turystycznej sołectwa Spała.
\end{abstract}

Słowa kluczowe: turystyka i rekreacja, GIS, funkcja turystyczna, atrakcyjność turystyczna, zdjęcie użytkowania ziemi, bonitacja punktowa.

\section{Wprowadzenie}

Kierunek studiów II stopnia Turystyka i Rekreacja prowadzony jest na Wydziale Nauk Geograficznych Uniwersytetu Łódzkiego. Podstawową dyscyplinę naukową, w ramach której prowadzone są badania nad turystyką i rekreacją, w odniesieniu do przestrzeni geograficznej, stanowi geografia turyzmu. Przedmiot badań geografii turyzmu obejmuje m.in. działalność człowieka w przestrzeni geograficznej, zarówno w szeroko rozumianym środowisku przyrodniczym, jak i środowisku antropogenicznym. W ramach tej dyscypliny prowadzone są badania współzależności zjawisk i procesów należących do dwóch sfer - przyrodniczej i antropogenicznej. Wymagają one wykorzystania kompetencji należących do wielu dziedzin nauki zarówno z obszaru nauk przyrodniczych, jak i obszaru nauk społecznych (Uniwersytet Łódzki 2018). 
Głównym celem kształcenia na kierunku Turystyka i Rekreacja jest wyposażenie absolwenta $\mathrm{w}$ wiedzę teoretyczną i umiejętności umożliwiające samodzielne badanie, analizowanie i syntetyzowanie relacji kształtujących przestrzeń turystyczną i rekreacyjną. Służy temu odpowiedni dobór przedmiotów, w tym ćwiczeń terenowych (Uniwersytet Łódzki 2018).

Przykładem takich ćwiczeń są ćwiczenia terenowe „Geografia turyzmu i hotelarstwa", których celem jest poznanie i zastosowanie odpowiednich metod badawczych i narzędzi oraz prawidłowe wnioskowanie. Jedną z metod badawczych są analizy przestrzenne. Umożliwiają one ujawnienie lub uzyskanie, na podstawie danych przestrzennych ${ }^{1}$ nowej informacji. Pozwalają na wskazanie potencjalnie interesujących wzorców przestrzennych, modelowanie, monitorowanie i prognozowanie wzajemnych relacji między środowiskiem przyrodniczym i antropogenicznym a działalnością gospodarczą człowieka, dynamiki tych relacji oraz ich wpływu na zmiany w funkcjonowaniu przestrzeni turystycznej i rekreacyjnej. Obecnie najbardziej rozpowszechnionym narzędziem badawczym służącym do przeprowadzania takich analiz, w oparciu o dane przestrzenne, są Systemy Informacji Geograficznej (GIS²) (Anselin, Getis 1992; Gaździcki 2003).

Celem artykułu jest przedstawienie metodologii badania funkcji turystycznej na przykładzie sołectwa Spała przy użyciu nowoczesnych technik komputerowych - ArcGIS Online i możliwości ich zastosowania do celów dydaktycznych.

\section{GIS}

Początki Systemów Informacji Geograficznej sięgają lat 60. XX wieku, ale intensywny ich rozwój rozpoczął się w latach 90 . XX wieku. Od tego czasu wzrastała też rola GIS w badaniach naukowych. Wraz z rozwojem GIS zmieniały się jego definicje. Jedną z najnowszych i najbardziej kompleksowych przedstawił R.F. Tomlinson (2007) prezentując model Systemu Informacji Geograficznej. Według tego autora GIS gromadzi w bazie danych dane przestrzenne pochodzące $\mathrm{z}$ różnych źródeł i wzbogacone o atrybuty opisowe, a następnie umożliwia

${ }^{1}$ Dane przestrzenne (spatial data) to dane dotyczące obiektów przestrzennych, w tym zjawisk i procesów, powiązanych z powierzchnią Ziemi, obiekty te mają charakter naturalny lub antropogeniczny (sztuczny). Dane dotyczą: właściwości geometrycznych obiektu przestrzennego, a zwłaszcza jego położenia względem przyjętego dwuwymiarowego lub trójwymiarowego układu współrzędnych, charakterystyki obiektu pod względem czasu, np. daty jego utworzenia, związków przestrzennych (topologicznych) danego obiektu z innymi obiektami przestrzennymi, wyróżnionych atrybutów opisowych obiektu przestrzennego, służących do jego identyfikacji oraz określających jego podstawowe właściwości (Gaździcki 2003; Litwin, Myrda 2005; Bielecka 2006).

${ }^{2}$ Geographic Information System - USA oraz Geographical Information System - Wielka Brytania, Kanada, Australia. 
operatorowi - użytkownikowi, w sposób interaktywny z wykorzystaniem narzędzi i funkcji analitycznych, ich zmianę w użyteczną informację poprzez utworzenie produktów informacyjnych.

Takim Systemem Informacji Geograficznej, działającym w chmurze, jest usługa ArcGIS Online (AGOL) oferowana przez firmę ESRI. AGOL umożliwia tworzenie map, przechowywanie, gromadzenie i analizowanie danych oraz ich udostępnianie innym użytkownikom $w$ ramach jednej instytucji lub poza nią. Pozwala również na współpracę wielu użytkowników w zdefiniowanych grupach. Usługa ArcGIS Online obsługuje też prace w terenie. Wykorzystując narzędzia i aplikacje (Collector for ArcGIS), AGOL umożliwia gromadzie danych w terenie, nawigowanie oraz koordynowanie i monitorowanie projektów wymagających współpracy wielu użytkowników. Taki System Informacji Geograficznej wykorzystano do przeprowadzenia ćwiczeń terenowych „geografia turyzmu i hotelarstwa”, ponieważ Wydział Nauk Geograficznych Uniwersytetu Łódzkiego posiada licencję typu site 3 ww. oprogramowania, co daje jego pełną funkcjonalność zarówno w wersji desktop ${ }^{4}$, jak i online ${ }^{5}$ (ESRI 2018).

\section{Obszar badań}

Ćwiczenia terenowe „Geografia turyzmu i hotelarstwa” od lat prowadzone są na terenie sołectwa Spała. Spała to niewielka miejscowość położona nad Pilicą w otoczeniu Spalskiego Parku Krajobrazowego, w powiecie tomaszowskim i gminie Inowłódz (ryc. 1). Jest to wieś, a od 2010 roku sołectwo Spała, które liczy sobie około 450 mieszkańców.

Spała powstała w XIX wieku jako carska stanica myśliwska pełniąca funkcję wypoczynkową. Była letnią rezydencją prezydentów Polski w okresie międzywojennym, a po II wojnie światowej jednym z najbardziej znanych ośrodków wypoczynkowych Funduszu Wczasów Pracowniczych (FWP) i sportowych Centralnego Ośrodka Sportu (COS). Po dziś dzień jest ważnym miejscem na turystycznej mapie Polski znanym z licznych wydarzeń, m.in. Dożynek Prezydenckich, Hubertusa i Jarmarków Spalskich. Po zmianie systemu gospodarczo-politycznego kraju w 1989 roku Spała pozostała obszarem ciągłych zmian i przez to stanowi ciekawy obiekt badań. Poza obszarami zabudowanymi i użytkowanymi rolniczo można uznać, że cała miejscowość pełni funkcję turystyczną ${ }^{6}$. Badania funkcji

\footnotetext{
${ }^{3}$ Licencja typu site to licencja bez limitów ilościowych.

${ }^{4}$ Oprogramowanie typu desktop jest zainstalowane na komputerze stacjonarnym.

${ }^{5}$ Online, czyli dostępny za pośrednictwem sieci komputerowej, w tym przypadku sieci Internet.

${ }^{6}$ Przez funkcję turystyczną rozumie się wszelką działalność społeczno-ekonomiczną w miejscowości lub regionie skierowaną na obsługę turystów, z której wynika jej/jego zdolność do zaspokojenia określonych potrzeb turystycznych (Kurek 2007).
} 


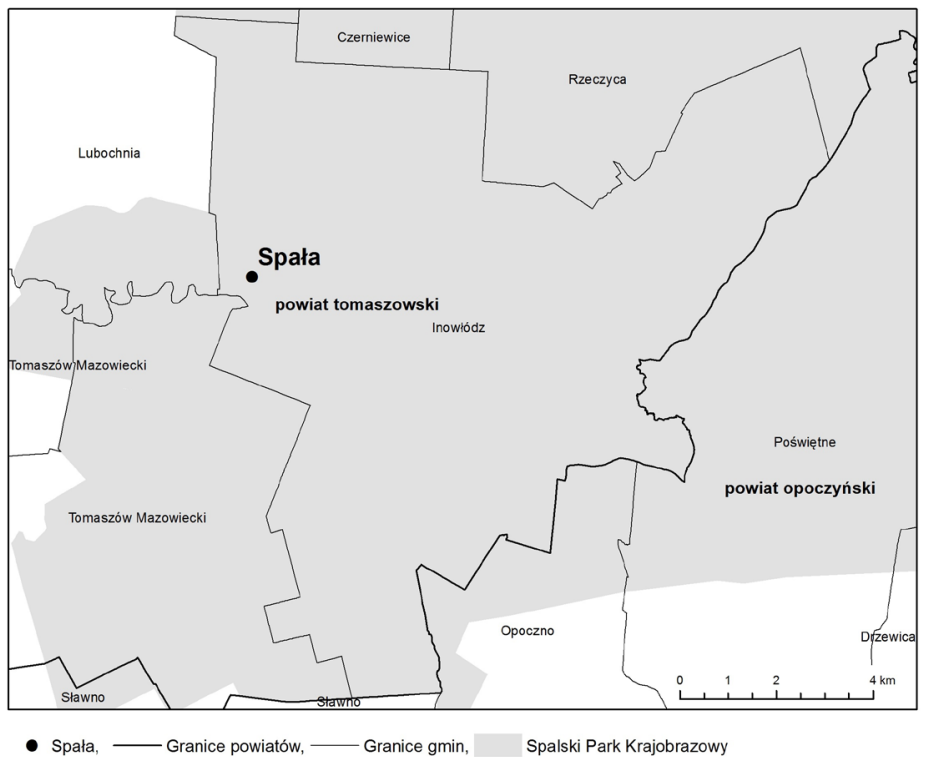

Ryc. 1. Położenie Spały

Źródło: opracowanie własne na podstawie danych Państwowego Rejestru Granic (PRG), Państwowego Rejestru Nazw Geograficznych (PRNG) i Generalnej Dyrekcji Ochrony Środowiska (GIOŚ).

turystycznej Spały prowadzone są od kilkudziesięciu lat przez łódzki ośrodek naukowy (Liszewski 1991; Latosińska, Żek 2011; Latosińska, Muszyńska 2013). W literaturze przedmiotu badania ruchu turystycznego i zagospodarowania turystycznego są najczęściej wskazywanymi miernikami funkcji turystycznej, a obliczone na ich podstawie wskaźniki/mierniki pozwalają ocenić funkcję turystyczną Spały jako bardzo rozwiniętą. Zatem Spała jest doskonałym poligonem doświadczalnym dla prowadzenia badań terenowych, m.in. z geografii turyzmu i hotelarstwa i może stać się wzorem dla podejmowania badań na innych obszarach i w innych miejscowościach. Ćwiczenia terenowe były próbą rozszerzenia badań nad funkcją turystyczną Spały o analizy przestrzenne - zdjęcie użytkowania ziemi i waloryzację turystyczną metodą bonitacji punktowej. Przeprowadzenie ćwiczeń oparte zostało na wykorzystaniu technologii GIS.

\section{Metody}

Podczas ćwiczeń terenowych zastosowano dwie przestrzenne metody określenia funkcji turystycznej badanego sołectwa:

- zdjęcie użytkowania ziemi oraz

- bonitację punktową. 
Zdjęcie (mapa) użytkowania ziemi zawiera informacje o aktualnym stanie wykorzystania przestrzeni w odniesieniu do działek geodezyjnych. Aktualizacja jest wynikiem zastosowania określonej klasyfikacji. Może być prowadzona metodami: pośrednią i bezpośrednią. Metoda pośrednia polega na interpretacji zdjęć lotniczych lub ortofotomapy, natomiast metoda bezpośredniego kartowania terenu wymaga identyfikacji, weryfikacji i aktualizacji w terenie wykorzystania danej działki geodezyjnej.

Podczas ćwiczeń terenowych, zgodnie z założeniami teoretycznymi, prace przebiegały dwuetapowo. W pierwszej kolejności studenci, na podstawie ortofotomapy, zapoznali się z terenem i wstępnie określili użytkowanie działek. Następnie podjęli działania $\mathrm{w}$ terenie zmierzające do weryfikacji istniejącego stanu. Kryterium klasyfikacji w terenie było określenie funkcji jaką pełni budynek na danej działce. Podstawą tej klasyfikacji funkcjonalnej były dane z Ewidencji Gruntów i Budynków (EGiB), pozyskane z Urzędu Gminy Inowłódz oraz podziały i klasyfikacje terenów miejskich autorstwa S. Liszewskiego (1978) - Tereny miejskie, podziat i klasyfikacja, jak również badania bezpośrednie w terenie. Zdecydowano się na zastosowanie klasyfikacji Liszewskiego, ponieważ Spała nie ma typowo wiejskiego charakteru. Przygotowanie badań terenowych wymagało od prowadzących opracowania odrębnej klasyfikacji terenów wykorzystywanych turystycznie na bazie istniejących podziałów (wymienione na ryc. 3). Za podstawę utworzenia legendy mapy przyjęto Rozporządzenie Ministra Infrastruktury $z$ dnia 26 sierpnia 2003 roku w sprawie wymaganego zakresu projektu miejscowego planu zagospodarowania przestrzennego ${ }^{7}, \mathrm{w}$ szczególności podstawowych barwnych oznaczeń graficznych i literowych dotyczących przeznaczenia terenów, które należy stosować na projekcie rysunku planu miejscowego. Zdjęcie użytkowania ziemi/użytkowanie ziemi jest podstawą do wykonania bilansu użytkowania ziemi. Obszar bilansować można za pomocą liczby działek pełniących daną funkcję w stosunku do ogólnej liczby działek lub do powierzchni.

Metoda bonitacji punktowej może być przydatna w ocenie atrakcyjności turystycznej obiektu, miejscowości, regionu/obszaru, a atrakcyjność turystyczną można traktować jako wyznacznik funkcji turystycznej. Atrakcyjność turystyczna jest pojęciem złożonym. Oprócz istniejących obiektywnie warunków środowiskowych (przyrodniczych i społeczno-ekonomicznych), dużą rolę w jej ocenie odgrywa czynnik subiektywny. Należy rozpatrywać ją kompleksowo, gdyż decydują o niej walory turystyczne, dostępność komunikacyjna oraz podaż usług związanych z zagospodarowaniem obszarów odwiedzanych/recepcyjnych. Jest to pojęcie integrujące elementy, które stanowią podstawę rozwoju ruchu turystycznego (Warszyńska, Jackowski 1979).

\footnotetext{
${ }^{7}$ Dz.U., 2003, nr 164, poz. 1587.
} 
Zdaniem J. Kaczmarka, A. Stasiaka i B. Włodarczyka (2005), atrakcyjność turystyczna to zasoby strukturalne potencjału turystycznego ${ }^{8}$ (walory turystyczne, zagospodarowanie turystyczne, dostępność komunikacyjna i inne). Walory (zasoby) turystyczne definiowane są jako: ,zespół elementów środowiska naturalnego oraz elementów pozaprzyrodniczych, które wspólnie lub każde z osobna są przedmiotem zainteresowania turystów i decydują o atrakcyjności turystycznej" (Kurek 2007: 24-25). Z pojęciem walorów turystycznych utożsamia się termin zasoby turystyczne, który według A. Kowalczyka (2000) jest szerszy i odnosi się do obiektywnie istniejących atrybutów środowiska przyrodniczego i społecznego (tzw. walory potencjalne), które stają się faktycznymi walorami turystycznymi dopiero po dokonaniu przez turystę ich pozytywnej oceny w procesie percepcji. Wśród ogółu walorów (zasobów) turystycznych można wydzielić walory przyrodnicze i walory antropogeniczne (pozaprzyrodnicze).

Bonitacja punktowa to metoda pozwalająca na uzyskanie obiektywnego, kompleksowego obrazu potencjału turystycznego danego obszaru (lub tylko wybranych jego elementów). Polega na przyporządkowaniu - według wcześniej przyjętych kryteriów - sumy punktów bonitacyjnych poszczególnym jednostkom badawczym o charakterze punktowym (np. miejscowości) lub powierzchniowym (np. jednostki administracyjne czy równopowierzchniowe pola wyznaczone przez nałożoną na mapę siatkę kwadratów lub heksagonów). Punkty można przy tym przyznawać zarówno za występowanie w danej jednostce analizowanych elementów potencjału turystycznego (punkty dodatnie), jak i za ich barak lub niską jakość (punkty ujemne).

Wyniki bonitacji punktowej prezentowane są w sposób kartograficzny:

- w przypadku punktowych jednostek badawczych - za pomocą metody sygnaturowej (wielkość sygnatury oznacza stopień natężenia/rangę zjawiska);

- w przypadku jednostek powierzchniowych - za pomocą kartogramu (intensywność zjawiska wyraża skala barw lub szraf) (Kaczmarek, Stasiak, Włodarczyk 2005).

\footnotetext{
${ }^{8}$ Potencjał turystyczny to ,wszystkie te elementy środowiska geograficznego oraz zachowania człowieka, które mogą być wykorzystane do uprawiania bądź zajmowania się turystyką, zostały nazwane potencjałem turystycznym. Potencjał turystyczny obejmuje więc wszelkie zasoby strukturalne i funkcjonalne warunkujące rozwój turystyki na określonym terenie" (Kaczmarek, Stasiak, Włodarczyk 2005: 51-52). Elementy potencjału turystycznego to zasoby strukturalne (walory turystyczne, zagospodarowanie turystyczne, dostępność komunikacyjna, inne) oraz zasoby funkcjonalne (ekonomiczne, technologiczne, ekologiczne, polityczne, psychologiczne, społeczno-demograficzne, kulturowe).
} 


\section{Metodologia badania z zastosowaniem nowoczesnej metody ArcGIS Online}

Obie opisane powyżej metody określania funkcji turystycznej łączy wspólny element w postaci przypisywania obiektom (działkom geodezyjnym lub jednostkom badawczym) pewnych atrybutów - wartości lub cech. Taki schemat działania odzwierciedla ideę GIS, gdzie w bazie danych przechowywane są informacje o obiektach występujących w przestrzeni powiązanych z opisującymi je atrybutami. Dlatego w celu przeprowadzenia ćwiczeń zdecydowano się na wykorzystanie technologii GIS. To rozwiązanie wymaga jednak znacznych nakładów pracy osób prowadzących ćwiczenia. Ich przeprowadzenie można podzielić na etapy:

I. Przygotowanie materiałów i projektów ćwiczeń;

II. Wprowadzenie studentów w wykonanie ćwiczeń;

III. Nadzór nad przebiegiem prac;

IV. Zestawienie i prezentacja wyników prac studentów.

W etapie I do przygotowania ćwiczeń wykorzystano oprogramowanie ArcGIS w wersji desktop (10.4) i online. Realizację tego etapu rozpoczęto od zgromadzenia literatury dotyczącej miejscowości Spała, jej historii i rozwoju. Następnie pozyskano dane przestrzenne z obszaru badań, z różnych źródeł. Należały do nich dane o reprezentacji:

1. Wektorowej':

1.1. Baza Danych Obiektów Topograficznych (BDOT) - klasa obiektów Budynki (kod: BUBD) z Urzędu Marszałkowskiego Województwa Łódzkiego Departamentu Geodezji i Kartografii;

1.2. Dane katastralne (działki geodezyjne) z Urzędu Gminy Inowłódz;

1.3. Dane o formach ochrony przyrody: rezerwaty, parki krajobrazowe, obszary chronionego krajobrazu, Natura 2000 specjalne obszary ochrony, zespoły przyrodniczo-krajobrazowe z Generalnej Dyrekcji Ochrony Środowiska (GIOŚ).

2. Rastrowej ${ }^{10}$ :

2.1. Mapy topograficzne z Państwowego Zasobu Geodezyjnego i Kartograficznego.

3. Analogowej:

3.1. Plany i mapy analogowe z różnych opracowań, w tym plany Spały z 1910 roku i początku lat 70. XX wieku oraz mapę granic sołectwa Spała.

${ }^{9}$ Dane wektorowe to dane przestrzenne w postaci współrzędnych opisujących właściwości geometryczne obiektów przestrzennych. Przechowywane w geobazie jako klasy obiektów (feature classes) (Gaździcki 2003).

${ }^{10}$ Dane rastrowe to dane przestrzenne odniesione do rastra, czyli dwuwymiarowej tablicy pól podstawowych, wierszy i kolumn, którym przypisano atrybuty. Przechowywane w geobazie jako zestawy danych rastrowych (raster datasets) (Gaździcki 2003; Longley i in. 2006). 
Następnym krokiem w etapie I było przygotowanie projektów ćwiczeń w programie ArcGIS desktop. Prace rozpoczęto od utworzenia geobazy ${ }^{11}$, która stanowiła repozytorium wszystkich danych przestrzennych niezbędnych do przeprowadzenia ćwiczeń. Na podstawie zebranych materiałów zwektoryzowano i zapisano jako klasę obiektów granicę sołectwa Spała, które stanowiło obszar badań. Bazując na wyznaczonych granicach opracowania zapisano w geobazie jako klasy obiektów:

- działki geodezyjne leżące w sołectwie Spała, które posłużyły do wykonania zdjęcia użytkowania ziemi;

- siatkę heksagonów o powierzchni $0,02 \mathrm{~km}^{2}$ i boku długości $100 \mathrm{~m}$ stworzoną za pomocą narzędzia Repeating Shapes for ArcGIS $S^{12}$, których użyto jako powierzchniowych jednostek badawczych w metodzie bonitacji punktowej.

Dla każdej z wymienionych klas obiektów zdefiniowano atrybuty, których wartości miały zostać pozyskane $\mathrm{w}$ trakcie realizacji ćwiczeń przez studentów. W większości przypadków wartości atrybutów zostały zapisane w domenach w geobazie, co oznacza, że wprowadzający dane może nadać wyłącznie wartości z określonego zestawu, wybierając je z listy. Takie rozwiązanie ułatwia pracę i minimalizuje możliwość popełnienia błędu.

Wykonanie zdjęcia użytkowania ziemi wymagało pozyskania wartości tylko dwóch atrybutów: funkcji działki oraz w przypadku użytków rolnych ich rodzaju, np. grunt orny, sad, łąka lub pastwisko. W przypadku metody bonitacji punktowej każda powierzchniowa jednostka badawcza (heksagon) miała przypisane 23 atrybuty dotyczące walorów naturalnych i antropogenicznych (w tym zagospodarowania) (tab. 1).

W tym ćwiczeniu zadaniem studentów było nie tylko stwierdzenie występowania danej cechy w polu podstawowym, ale również jej pomiar (np. liczby obiektów, długości szlaków) i przypisanie odpowiedniej, określonej przez osoby przygotowujące ćwiczenie, liczby punktów związanych z jej występowaniem w danej jednostce badawczej. Należy podkreślić, że w przypadku obu opisywanych ćwiczeń, zdefiniowane atrybuty są dostosowane do charakteru obszaru badań.

${ }^{11}$ Geobaza - baza danych przestrzennych, inaczej nazywana bazą danych geograficznych, to format przechowywania danych, przy użyciu technologii (modelu) relacyjnego baz danych. Pozwala na przechowywanie i zarządzanie danymi przestrzennymi (MacDonald 2001; Lemańczyk 2009).

${ }^{12}$ Repeating Shapes for ArcGIS to narzędzie stworzone w 2012 roku i udostępnione przez firmę Jenness Enterprises. Jego autorem jest Jeff Jenness. Narzędzie dedykowane jest naukowcom oraz osobom zajmującym się gospodarką przestrzenną, które wykonują analizy wymagające dzielenia krajobrazu, czyli obszaru badań w sposób systematyczny na równe jednostki przestrzenne. Według autora narzędzie szczególnie przydatne jest w tworzeniu projektów monitorowania i próbkowania. Repeating Shapes for ArcGIS jest kompatybilne z oprogramowaniem ArcGIS w wersjach 9.x i 10.x (Jenness 2012). 
Tabela 1. Rodzaje atrybutów w metodzie bonitacji punktowej

\begin{tabular}{|c|c|c|}
\hline $\begin{array}{c}\text { Rodzaj } \\
\text { walorów }\end{array}$ & Opis & Miara \\
\hline \multirow{11}{*}{ 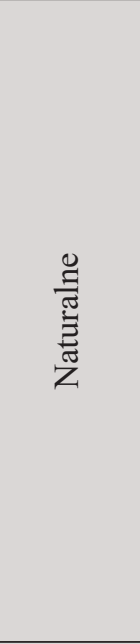 } & \multirow{2}{*}{ Obszary leśne } & Udział \% w powierzchni heksagonu \\
\hline & & Dominujący gatunek drzew \\
\hline & \multirow{2}{*}{ Wody } & Stojąca: udział \% w powierzchni heksagonu \\
\hline & & Płynąca: długość w m w heksagonie \\
\hline & Brzeg & Dostępność: w \% długości brzegu \\
\hline & Wysokości n.p.m. & Różnica wysokości w m \\
\hline & \multirow{2}{*}{ Obszary chronione } & Udział \% w powierzchni heksagonu \\
\hline & & Rodzaj \\
\hline & Zróżnicowanie krajobrazu & Liczba krajobrazów \\
\hline & Pomniki przyrody & Liczba obiektów \\
\hline & Osobliwości przyrody & Liczba obiektów \\
\hline \multirow{12}{*}{ 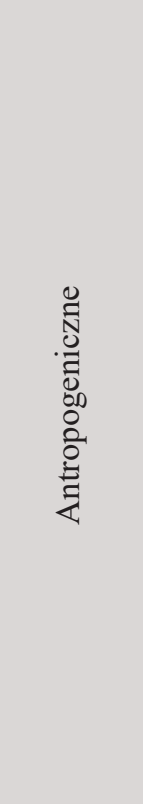 } & Zabytki & Liczba obiektów \\
\hline & Obiekty małej architektury & Liczba obiektów \\
\hline & Muzea & Liczba obiektów \\
\hline & $\begin{array}{l}\text { Baza noclegowa } \\
\text { (całoroczna i sezonowa) }\end{array}$ & Liczba miejsc noclegowych \\
\hline & $\begin{array}{l}\text { Baza gastronomiczna } \\
\text { (całoroczna i sezonowa) }\end{array}$ & Liczba miejsc konsumenckich \\
\hline & $\begin{array}{l}\text { Baza towarzysząca } \\
\text { (również paraturystyczna) }\end{array}$ & Liczba obiektów \\
\hline & \multirow{6}{*}{ Baza komunikacyjna } & Liczba obiektów \\
\hline & & Kategoria zarządzania drogi \\
\hline & & Długość dróg \\
\hline & & Długość szlaków \\
\hline & & Rodzaj szlaków \\
\hline & & Kolory szlaków \\
\hline
\end{tabular}

Źródło: opracowanie własne.

Dla każdego ćwiczenia utworzono osobny projekt w programie ArcGIS desktop. W projekcie ćwiczenia zdjęcia użytkowania ziemi dodano warstwę pomocniczą w postaci budynków pozwalającą na lepszą identyfikację działki w terenie 
(ryc. 2), a w projekcie ćwiczenia metody bonitacji punktowej dołączono warstwy zawierające granice obszarów chronionych. $\mathrm{W}$ obu projektach wprowadzono też warstwy z podziałem na mniejsze obszary opracowania (indywidualne obszary opracowania dla zespołów badawczych pracujących w terenie). Następnie każdy z projektów opublikowano jako usługę w serwisie ArcGIS Online. Projekty zostały zapisane w zasobach na koncie ArcGIS Online osoby publikującej w postaci hostowanych warstw (Featuer Layer i Tile Layer). Używając opublikowanych warstw utworzono mapy (Web map) osobne dla każdego ćwiczenia (Jażdżewska, Lechowski 2018).

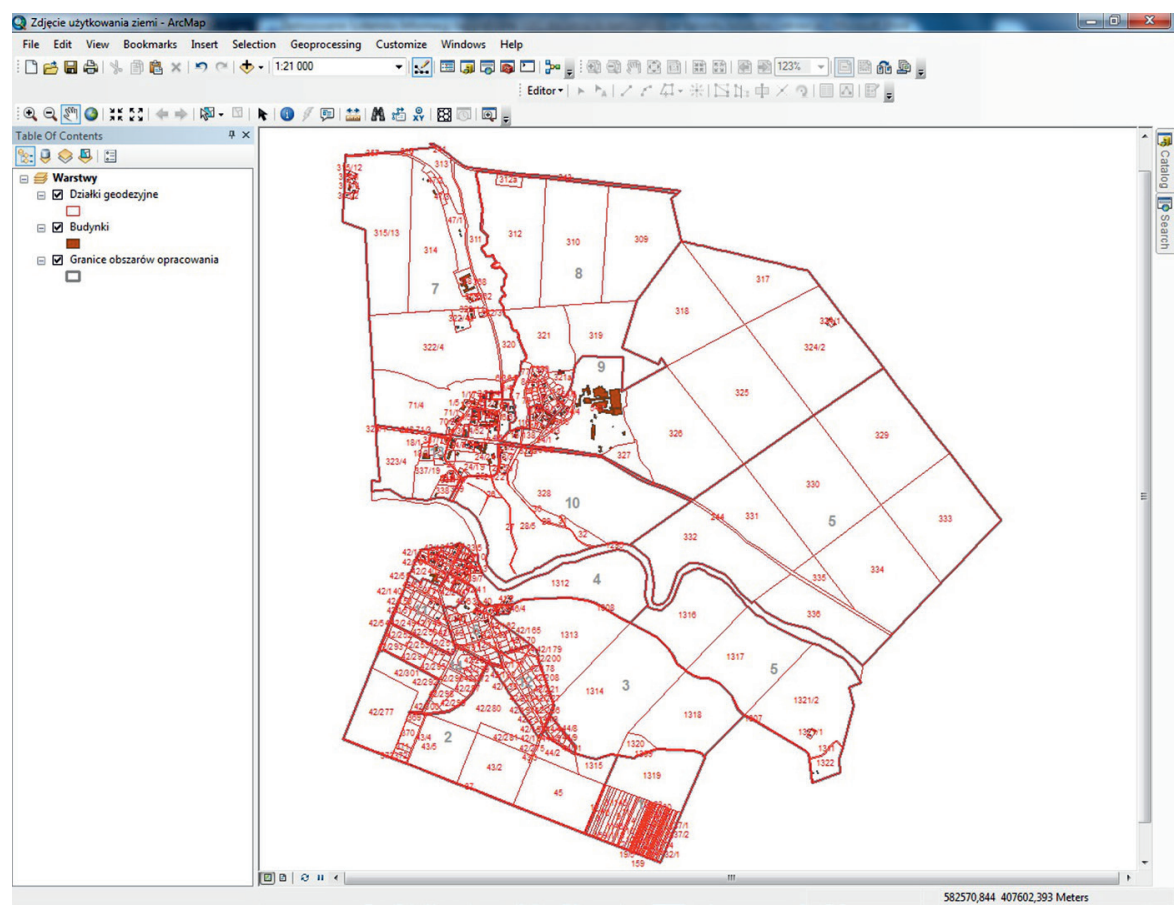

Ryc. 2. Projekt ćwiczenia zdjęcia użytkowania ziemi w programie ArcGIS 10.4 (desktop) Źródło: opracowanie własne.

Jednak aby możliwe było wykonanie ćwiczeń przez liczną grupę studentów, należało odpowiednio skonfigurować parametry opublikowanych warstw, przede wszystkim: działek geodezyjnych i powierzchniowych jednostek badawczych. W tym celu:

- włączono możliwości edycji, ale dopuszczającą tylko aktualizację atrybutów działek i heksagonów, co miało na celu uniknięcie przypadkowych, niepożądanych usunięć obiektów lub modyfikacji ich kształtu;

- włączono opcje śledzenia, która rejestruje kto z użytkowników, jako ostatni, zaktualizował dany obiekt; 
- włączono opcję synchronizacji, która pozwala na aktualizowanie danych pozyskanych w terenie, w trybie offline ${ }^{13}$;

- skonfigurowano okna podręczne wyłączając widoczność i możliwość edycji niektórych, nieistotnych dla wykonywanych ćwiczeń atrybutów (np. ID obiektów) oraz dodając wskazówki/podpowiedzi dla osób pozyskujących dane $\mathrm{w}$ terenie zawierające informacje o atrybutach $\mathrm{i}$ ich wartościach, np. liczbie punktów przyznawanych za wartość danej cechy w metodzie bonitacji punktowej.

Etap II realizacji ćwiczeń polegający na wprowadzeniu studentów w ich wykonanie rozpoczęto od utworzenia grupy ćwiczeniowej w portalu ArcGIS Online. Do grupy założonej przez prowadzącego ćwiczenia zastali zaproszeni/należeli wszyscy studenci biorący udział w ćwiczeniach. Następnie utworzone w etapie I mapy zostały udostępnione grupiećwiczeniowej. Wprowadzenie studentów w techniczne aspekty wykonania ćwiczenia rozpoczęto już w trakcie kameralnych zajęć z postaw GIS (20 godzin ćwiczeń), na których studenci nauczyli się podstaw obsługi oprogramowania ArcGIS zarówno w wersji desktop, jak i online. W trakcie ćwiczeń terenowych studentów zapoznano z teoretycznymi podstawami wykonania ćwiczeń (1 i 2), a także z charakterystyką obszaru badań, jego historią i topografią.

Grupa ćwiczeniowa została podzielona na dwuosobowe zespoły badawcze. Każdemu zespołowi zostały przypisane indywidualne obszary opracowania (po jednym do każdego z ćwiczeń). Do realizacji ćwiczeń wykorzystano urządzenia mobilne (tablety) z systemem operacyjnym Android i aplikacją Collector for ArcGIS, służącą do zbierania i aktualizacji danych w terenie we współpracy z subskrypcją ArcGIS Online dla organizacji. Posługując się urządzeniami mobilnymi zespoły zbierały dane $\mathrm{w}$ terenie, a następnie dokonały synchronizacji z mapą umieszczoną w portalu AGOL. Dzięki użyciu aplikacji Collector for ArcGIS możliwa była praca w terenie w trybie offline, a następnie synchronizacja danych z mapą na serwerze po powrocie do bazy, gdzie uruchomiony był punkt dostępowy do sieci Internet (ESRI 2018).

Praca w chmurze umożliwiła prowadzącym stały nadzór nad postępem prac w każdym ćwiczeniu (etap III), a synchronizacja danych pozwalała na bieżąco sprawdzać poprawność i kompletność pozyskiwanych danych oraz korygować błędy. Na koniec trwających 4 dni ćwiczeniowych prac terenowych odbyło się podsumowanie i prezentacja wyników (etap IV). Dzięki możliwości wykonywania obliczeń i zmiany stylu (symbolizacji) obiektów oraz narzędziom analiz na mapach utworzonych w portalu ArcGIS Online, prezentacja wyników możliwa była już w miejscu odbywania ćwiczeń terenowych ${ }^{14}$.

\footnotetext{
${ }^{13}$ Offline, czyli bez dostępu do sieci Internet.

${ }^{14} \mathrm{Z}$ użyciem przenośnego komputera (laptop) i rzutnika multimedialnego.
} 
Grupa 30 studentów podzielona na 15 zespołów badawczych zbadała funkcje 706 działek geodezyjnych o łącznej powierzchni ponad 1130 ha oraz potencjał turystyczny 493 jednostek badawczych. Uzyskane wyniki zdjęcia użytkowania ziemi (ryc. 3) były podstawą wykonania bilansu użytkowania ziemi. Używając narzędzia „Analiza” wykonano agregację działek na podstawie przypisanej funkcji, dodatkowo dodając pola, w których wyznaczona została liczba i sumaryczna powierzchnia działek o danej funkcji. Wykonano też symbolizację warstwy działek geodezyjnych według przypisanej funkcji zgodnej z oznaczeniami barwnymi stosowanymi w miejscowych planach zagospodarowania przestrzennego. Otrzymane wyniki wykazały, że pod względem liczby działek najwięcej zajmują tereny mieszkaniowe zabudowane i niezabudowane (po 182 działki), a następnie tereny komunikacyjne (94 działki), użytki rolne (91 działek) i lasy (67 działek). Natomiast tereny turystyczno-rekreacyjne zabudowane i niezabudowane zajmują odpowiednio 47 i 24 działki, a tereny usługowo-turystyczno-rekreacyjne - 2 działki. Wody zajmują 9 działek ,a tereny mieszkaniowo-usługowe - 6. Jako pojedyncze działki występują tereny mieszkaniowo-usługowe i tereny sportowe. Natomiast pod względem zajmowanej powierzchni, zdecydowanie dominują lasy (846 ha) i użytki rolne (112 ha). Tereny mieszkaniowe zabudowane i niezabudowane stanowią łącznie 46 ha, a tereny turystyczno-rekreacyjne zabudowane i niezabudowane oraz tereny usługowo-turystyczno-rekreacyjne ponad 48 ha. Tereny sportowe zajmują ponad 21 ha. Pozostałe tereny: komunikacyjne (32 ha), wody (24 ha), mieszkaniowo-usługowe (1,6 ha) i usługowe $(0,1 \mathrm{ha})$ łącznie pokrywają 56,7 ha powierzchni badanego obszaru. $Z$ bilansu użytkowania ziemi wynika, że tereny pełniące funkcje turystyczne i rekreacyjne stanowią ponad $10 \%$ wszystkich działek i ponad 4\% powierzchni Sołectwa Spała. Przy czym należy uwzględnić, że obszary leśne znajdujące się w sołectwie Spała są otwartą przestrzenią rekreacyjną chętnie wykorzystywaną przez turystów, co potwierdza dalsze badanie atrakcyjności turystycznej wykonane metodą bonitacji punktowej.

Uzyskanie wyników badania funkcji turystycznej Spały metodą bonitacji punktowej polegało na dodaniu pola w tabeli atrybutów warstwy powierzchniowych jednostek badawczych i zsumowaniu w nim pól zawierających punkty przypisane wartości każdego atrybutu. Uzyskane wyniki wykazały, że powierzchniowe jednostki badawcze (heksagony) uzyskały od 0,5 do 26 punktów. Średnia wyniosła 8,2 punktu. Następnie zmieniono symbolizację tej warstwy według sumy uzyskanych przez każdy heksagon punktów, dokonując klasyfikacji w oparciu o naturalne grupowanie danych (naturalne przerwy) i tworząc 5 klas (ryc. 4). Najwyższe pod względem liczby uzyskanych punktów (16,4-26 pkt) wyniki osiągały jednostki badawcze położone w Spale, w centrum miejscowości i nad rzekami Pilicą i Gacią. To wskazuje, że te tereny sołectwa Spała są najbardziej atrakcyjne pod względem turystycznym. Wysokie wyniki (11,4-16,4 pkt) uzyskały też heksagony rozmieszczone wzdłuż głównych szlaków komunikacyjnych i turystycznych 
Start ₹ Zdjęcie użytkowania ziemi

Nowa mapa * Utwórz prezentację

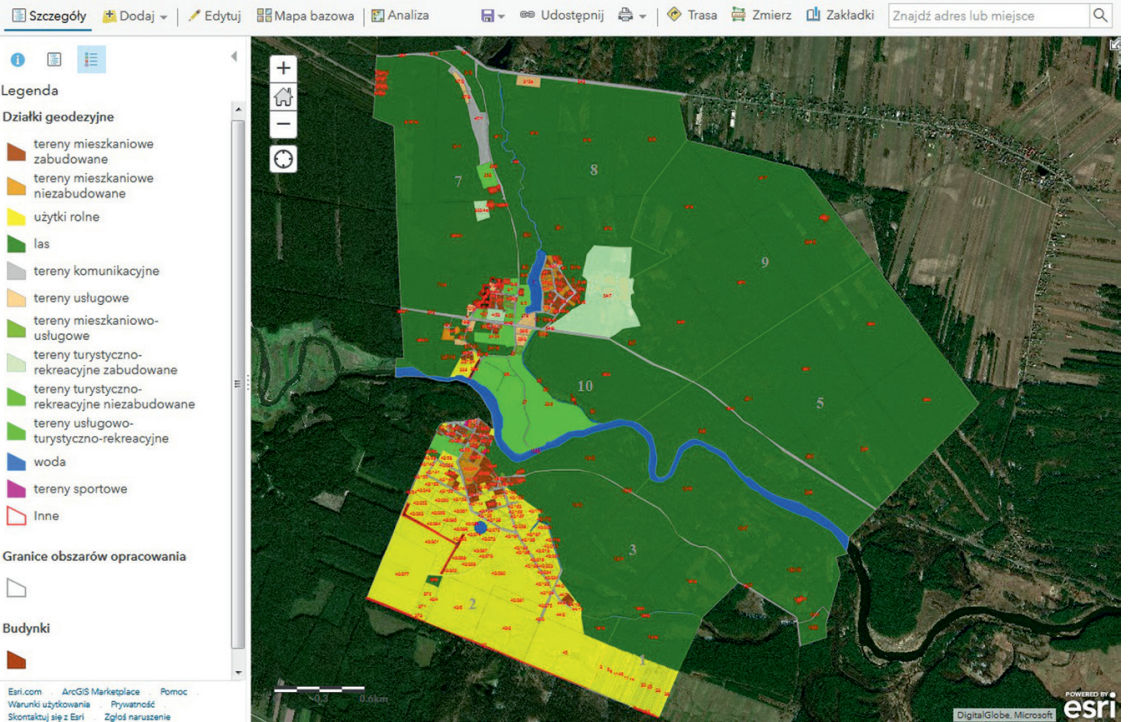

Ryc. 3. Zdjęcie użytkowania ziemi sołectwa Spała w portalu ArcGIS Online Źródło: opracowanie własne.

Start $\times$ Metoda bonitacji punktowej

Nowa mapa ₹ Utwórz prezentację

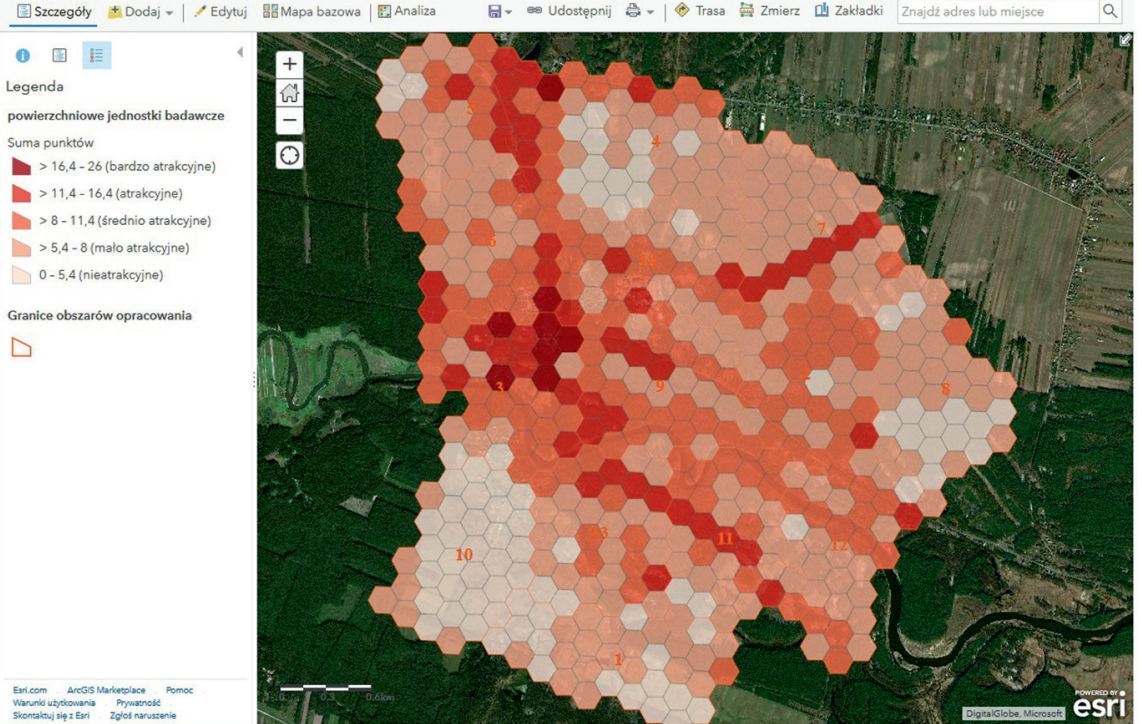

Ryc. 4. Ocena atrakcyjności turystycznej sołectwa Spała metodą bonitacji punktowej w portalu ArcGIS Online

Źródło: opracowanie własne. 
przebiegających przez obszary lasów otaczających Spałę. Jako najmniej atrakcyjne pod względem turystycznym $\mathrm{w}$ badaniu wypadły tereny usytuowane w południowo-wschodniej części obszaru badań, zajęte głównie przez użytki rolne, ponieważ tam widoczne jest największe skupisko powierzchniowych jednostek badawczych, które uzyskały najsłabsze wyniki (poniżej 5,4 pkt).

Wyniki badań terenowych zostały omówione i zaprezentowane na forum grupy ćwiczeniowej, ale mapy z nadaną symbolizacją były też dostępne dla każdego z uczestników ćwiczeń w portalu ArcGIS Online, również za pomocą urządzeń mobilnych.

\section{Podsumowanie}

W artykule przedstawiono metodologię i wyniki badania funkcji turystycznej sołectwa Spała z zastosowaniem dwóch metod przestrzennych: zdjęcia użytkowania ziemi i bonitacji punktowej z użyciem Systemu Informacji Geograficznej - ArcGIS Online. Uzyskane wyniki wskazują, że funkcja turystyczna sołectwa Spała jest bardzo rozwiniętą. Tereny pełniące funkcje turystyczne i rekreacyjne stanowią znaczny odsetek (ponad 10\%) działek geodezyjnych i powierzchni (ponad 4\%) badanego obszaru. Natomiast najbardziej atrakcyjne pod względem turystycznym są tereny położone w Spale, w centrum miejscowości i nad rzekami Pilicą i Gacią oraz wzdłuż głównych szlaków komunikacyjnych i turystycznych.

Badania były prowadzone w ramach ćwiczeń terenowych „Geografia turyzmu i hotelarstwa" i pozwoliły na zrealizowanie celu ćwiczeń, którym było przygotowanie studentów do zebrania i opracowania materiałów niezbędnych do napisania pracy magisterskiej. Często podejmowanym tematem prac magisterskich jest funkcja turystyczna obiektu, miejscowości lub obszaru. Natomiast doświadczenia dydaktyczne wskazują, że najwięcej problemów sprawia studentom stosowanie metod analizy przestrzennej. Zatem przećwiczenie zastosowania wymienionych metod na konkretnym przypadku/terenie wydaje się z dydaktycznego punktu widzenia bardzo zasadne.

Dużym walorem zastosowanej metodologii było użycie najnowocześniejszych rozwiązań technologicznych i narzędzi z zakresu Systemów Informacji Geograficznej, w tym pracy w „chmurze” i z urządzeniami mobilnymi. Pozwoliło to na:

- zebranie dużej ilości danych przestrzennych w krótkim czasie;

- rozwijanie u studentów umiejętności współdziałania i pracy w grupie;

- stały nadzór prowadzących nad postępem prac w terenie i poprawnością pozyskanych danych, co skłaniało studentów do bardziej regularnej i sumiennej pracy;

- dostępność wyników badań i możliwość ich omówienia bezpośrednio w trakcie ćwiczeń terenowych. 
Należy jednak podkreślić, że przeprowadzenie badań wymaga wcześniejszego przygotowania studentów/użytkowników do pracy w Systemach Informacji Geograficznej oraz znacznych nakładów pracy osób prowadzących badania/ćwiczenia, związanych z zaplanowaniem prac, pozyskaniem danych przestrzennych, przygotowaniem projektów i map, stałym nadzorem nad postępem prac oraz przedstawieniem wyników końcowych.

\section{Literatura}

Anselin L., Getis A., 1992, Spatial statistical analysis and geographic information systems, „The Annals of Regional Science”, 26(1): 19-33.

Bielecka E., 2006, Systemy informacji geograficznej. Teoria i zastosowania, Wydawnictwo Polsko-Japońskiej Wyższej Szkoły Technik Komputerowych, Warszawa.

ESRI, 2018, Czym jest ustuga ArcGIS Online?, https://doc.arcgis.com/pl/arcgis-online/ reference/what-is-agol.htm (dostęp: 27.12.2018).

Gaździcki J., 2003, Leksykon geomatyczny, Polskie Towarzystwo Informacji Przestrzennej.

Jażdżewska I., Lechowski Ł., 2018, Wstęp do geoinformacji z ArcGIS, Wydawnictwo Uniwersytetu Łódzkiego, Łódź.

Jenness J., 2012, Repeating shapes for ArcGIS. Jenness Enterprises, http://www.jennessent.com/arcgis/repeat_shapes.htm (dostęp: 10.11.2018).

Kaczmarek J., Stasiak A., Włodarczyk B., 2005, Produkt turystyczny, Wydawnictwo Naukowe PWN, Warszawa.

Kowalczyk A., 2000, Geografia turyzmu, Wydawnictwo Naukowe PWN, Warszawa.

Kurek W. (red.), 2007, Turystyka, Wydawnictwo Naukowe PWN, Warszawa.

Latosińska J., Muszyńska A., 2013, Stare i nowe formy turystyki w przestrzeni - Spalski Jarmark Antyków i Rękodzieła Ludowego w świetle badań ruchu turystycznego, Warsztaty z Geografii Turyzmu: Nowe-stare formy turystyki w przestrzeni, 3, Wydawnictwo Uniwersytetu Łódzkiego, Łódź: 137-157.

Latosińska J., Żek M., 2011, Funkcja turystyczna Spaty, Warsztaty z Geografii Turyzmu: Turystyka polska w latach 1989-2009, Wydawnictwo Uniwersytetu Łódzkiego, Łodź: 93-115.

Lemańczyk K., 2009, Typy Geobaz w ArcGIS, http//www.npgc.pl/index.php/2009/05/ typy-geobaz-w-arcgis/ (dostęp: 26.09.2017).

Liszewski S., 1978, Tereny miejskie. Podziat i klasyfikacja, „Acta Universitatis Lodziensis", Zeszyty Naukowe Uniwersytetu Łódzkiego, Nauki Matematyczno-Przyrodnicze, seria II(15): 3-33.

Liszewski S., 1991, Spała. Morfologia i funkcja miejscowości wypoczynkowej, „Turyzm”, 2: $5-32$.

Litwin L., Myrda G., 2005, Systemy Informacji Geograficznej. Zarzadzanie danymi przestrzennymi w GIS, SIP, SIT, LIS, Wydawnictwo HELION, Gliwice.

Longley P., Goodchild M., Maguire D., Rhin D., 2006, GIS. Teoria i praktyka. Przektad pod redakcja naukowa A. Magnuszewskiego, Wydawnictwo Naukowe PWN, Warszawa.

MacDonald A., 2001, Building a geodatabase, ESRI Redlands.

Tomlinson R.F., 2007, Rozważania o GIS: planowanie Systemów Informacji Geograficznej dla menedżerów, ESRI Polska. 
Uniwersytet Łódzki, 2018, Turystyka i Rekreacja - Studia II stopnia. Opis Studiów, http://informatory.uni.lodz.pl/wydzial-nauk-geograficznych/turystyka-i-rekreacja-3/ (dostęp: 22.11.2018).

Warszyńska J., Jackowski A., 1979, Podstawy geografii turyzmu, Państwowe Wydawnictwo Naukowe, Warszawa.

\title{
Akty prawne \\ Rozporzadzenie Ministra Infrastruktury z dnia 26 sierpnia 2003 roku $w$ sprawie wy- maganego zakresu projektu miejscowego planu zagospodarowania przestrzennego (Dz.U., 2003, nr 164, poz. 1587). \\ APPLICATION OF GEOGRAPHIC INFORMATION SYSTEMS (GIS) IN GEOGRAPHIC DIDACTICS. EXAMPLE OF TERRAIN EXERCISES "GEOGRAPHY OF TOURISM AND HOTEL INDUSTRY"
}

\begin{abstract}
The aim of the article is to present the methodology of study of the tourism function on the example of the Spała village with the use of Geographic Information Systems (GIS) and the possibility of using them for didactic purposes in the field of Tourism and Recreation on the example of field exercises "geography of tourism and hotel industry". The spatial range of field studies conducted as part of the exercises included the Spała village. During the exercise, two spatial methods for determining tourist function were used: land use map and point valuation. Exercises were carried out using GIS technology and tools, including ArcGIS 10.4 (desktop) and ArcGIS Online.

The obtained results indicate that the tourist function of the Spała village is well developed. Areas that perform tourist and recreational functions constitute a significant percentage (over 10\%) of plots and area (over 4\%) of the studied area. However, the most attractive in terms of tourism are the areas located in Spała, in the center of the village, on the Pilica and Gać rivers and along the main communication and tourist routes.

The great advantage of the presented methodology was the use of modern technological solutions and tools of Geographic Information Systems, including work in the cloud and with mobile devices. This allowed for:

- gathering a large amount of spatial data in a short time;

- developing students' skills of cooperation and teamwork;

- constant supervision of the progress of field work and the correctness of the data obtained, which prompted students to work more regularly and conscientiously;

- availability of research results and the possibility of discussing them directly during field exercises.
\end{abstract}

Keywords: tourism and recreation, GIS, tourist function, tourist attractiveness, land use map, point valuation. 
Dr Jolanta Latosińska Zakład Geografii Turyzmu Instytut Geografii Miast i Turyzmu Wydział Nauk Geograficznych Uniwersytet Łódzki e-mail: jolanta.latosinska@geo.uni.lodz.pl

Mgr inż. Marta Nalej Zakład Geoinformacji Instytut Geografii Miast i Turyzmu Wydział Nauk Geograficznych Uniwersytet Łódzki e-mail: marta.nalej@geo.uni.lodz.pl 